\title{
The Development And Management Of Organizational Partner Satisfaction
}

Valentina Stan, ESSCA School of Management, France

Barbara Caemmerer, ESSCA School of Management, France

\begin{abstract}
While the development of a partner orientation is critical for the achievement of strategic organizational objectives, little is known about the components of such an orientation and how they impact on partner satisfaction in service operations contexts. The objective of this study is to establish the antecedents of partner satisfaction in a complex service operations context. The achievement of partner satisfaction can be seen as being particularly important, as it forms the basis for partners' willingness to remain in a partnership. This is crucial in public sector contexts in which partnership work is usually concerned with the achievement of long-term strategic objectives.
\end{abstract}

This study contributes to the wider stakeholder literature and provides managerial implications for public administration.

Keywords: Partner Orientation; Partner Satisfaction; Perceived Value; Service Operations; PLS Path Modeling

\section{INTRODUCTION}

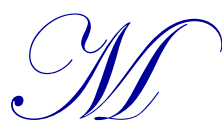

anaging relationships with different stakeholder groups is considered important for sustainable organizational success (Ferrell et al., 2010). To date, the majority of studies in this area have typically focused on customers, competitors, employees and shareholders as organizational key stakeholders. However, there is some concern that true stakeholder orientation should incorporate a wider range of groups that have an impact on the organization, or that are impacted by the organization (Ferrell and Ferrell, 2008).

This study contributes to the extant literature by researching how service operations can develop and manage a partner orientation as part of their stakeholder orientation. In line with relationship orientation literature (Grönroos, 1989), such orientation should be positively related to partner satisfaction, a pre-requisite for long-term, positive, and mutually beneficial organizational relationships with partners.

We are thus particularly interested in how the different components of partner orientation can lead to partner satisfaction and how organizations can effectively develop and manage relationships with partners.

The study has been carried out in a complex business-to-business service operations context, a UK-based economic development agency. The research setting is particularly interesting from an academic as well as practical perspective: While a good amount of stakeholder management research has been conducted in private business-tocustomer service operations, less is known about how concepts such as partner orientation and satisfaction may apply to long-lasting business-to-business service contexts, such as public and not-for-profit organizations (Olson et al., 2005).

However, as such contexts are particularly complex, due to the wide range of stakeholder groups and agendas such operations hold, it is important to understand in more detail how they can manage the relationships with their partners in more effective ways. This has become the case even more so in recent times, due to an increase in pressure of delivering more and better services to the public as well as dramatic funding cuts, public service entities are increasingly entering partnerships with a wide range of organizations (Buttimer, 2006; Hayes, 2002). 
Thus, the maintenance of successful relations with partners is crucial in public service operations contexts in order to guarantee the best value services for citizens in a sustainable manner (Maddock, 2002; Micheli et al., 2005). As such, the objective of this study is to establish the antecedents of partner satisfaction in a complex service operations context.

The following section provides an overview of the extant literature and outlines the development of hypotheses. This is followed by a description of the deployed research methodology. Key findings and managerial implications are discussed. Finally, the limitations of this study are highlighted and avenues for future research are outlined.

\section{LITERATURE REVIEW AND DEVELOPMENT OF HYPOTHESES}

\subsection{The Importance Of Stakeholder Orientation}

There is increasing evidence that general stakeholder orientation impacts organizational performance positively (e.g., Ferrell et al., 2010). As suggested by Freeman (1984), stakeholder theory posits a relational model of organizational behavior. Stakeholders are defined as individuals or groups that can impact the organization or that can be impacted by the organization (Freeman, 1984). Thus, the organization has to take the interests of these individuals and groups into account and create a relationship that is of value for both parties.

This notion is in line with neo-institutional theory, which suggests that organizations are part of networks with interrelated economic and institutional processes. Over the past three decades, this perspective has gained increasing attention in organizational research (Mizruchi and Fein, 1999). Neo-institutionalism is based on the notion that in order to survive by extracting resources from their environment, it is crucial for organizations to convince important the public that they are legitimate entities worthy of support (DiMaggio and Powell, 1983). Therefore, organizations concerned with their survival take on structures and adopt practices that are socially accepted in order to establish their legitimacy (Deephouse, 1996). Thus, a positive stakeholder orientation can help organizations earn acceptance amongst important stakeholder groups, gain increased support and ultimately valuable resources.

These, particularly in public sector contexts, do not need to be of monetary value, but could come in any other form such as positive contributions to organizational objectives through successful collaboration, know-how, interconnectedness or political influence.

\subsection{Partner Orientation As A Part Of Organizational Stakeholder Orientation}

The general recognition that stakeholder orientation is an important part of organizational strategy has attracted wide research attention. Previous studies have focused on the exploration of the orientation of organizations towards their customers, competitors, employees and shareholders (e.g., Kohli and Jaworski, 1990). However, organizational partners, though strategically important stakeholders, have widely been neglected in the literature.

It is for this reason that this study examines partner orientation as a part of wider organizational stakeholder orientation in more detail. In line with broader stakeholder theory, partner orientation can be defined as an organization's orientation towards the development and maintenance of relationships with partners that results in mutual exchange and fulfillment of promises (Ferrell et al., 2010; Harker, 1999).

The literature on strategic alliances suggests that complementarity of partners is crucial, including a strong vision to work towards one unified objective and resource fit (Luo, 2002).

On the basis of these observations, we define partners as individuals or organizations which enter into relationships with common objectives in order to create outcomes that are of mutual value. This is congruent with the public sector literature suggesting that value management, the division of responsibilities as well as the sharing of common goals are important pillars in public sector partnerships (Buttimer, 2006). 
However, despite these insights, there is little empirical knowledge about how partnerships can be managed in a manner that it leads to partner satisfaction.

This is important to understand, though, considering that the emphasis in partnership work is in the mainly on the achievement of strategic long-term goals, and satisfaction is recognized as an enabler for sustainable relationships (Grönroos, 1989). We have thus carried out empirical testing on how the different components of partnership orientation lead to partner satisfaction. Our conceptual model and the related hypotheses are presented in the next section.

\subsection{The Antecedents Of Partner Satisfaction - The Partner Value Chain}

Whilst the wider stakeholder and partner literature provide little insight into how partner satisfaction can be achieved, the concept of relationship orientation gives some indications. In general, relationship orientation is concerned with the development of mutually beneficial, long-term interactions between two parties (Panayides, 2007; Sin et al., 2005), such as organizational partners, which should positively impact value perceptions (Morgan and Hunt, 1994; Sin et al., 2005).

Further on, we present the Partner Value Chain.

\subsubsection{Complementarity Of Partners}

The similarity and fit between partners has attracted great attention in the literature on strategic alliances (Beckman et al., 2004). There is evidence that if partners possess and work towards the development of complementary goals, skills and resources, coordination and collaboration become more seamless and thus increase partner attractiveness (Harrison et al., 2001).

According to Chung et al. (2000), "the choice of partners is heavily influenced by considerations related to the resource complementarity of partners".

Therefore, complementarity is argued to be a fundamental requirement for any type of partnership work (Shah and Swaminathan, 2008). Particularly in complex operational contexts where outcome predictability is low, perceptions of partner complementarity may be a crucial enabler to initiate collaboration in the first place, as it increases the willingness for mutual exchange and can provide a basis for collaboration with integrity (Shapiro and Brett, 2005).

\subsubsection{Exchange Between Partners}

Organizations that put an emphasis on proactive and meaningful exchange are more likely to learn about their partners (Nonaka, 1994).

As suggested by Eweje and Palakshappa (2011) "collaborations offer a form of engagement that can utilize the strengths of both partners to produce gains of value to many stakeholders".

If exchange is taken seriously, the organization and its partners can arrive at shared interpretations about crucial collaborative aspects and thus enhance the mutual understanding of the needs and objectives of both sides (Sin et al., 2005).

The establishment of congruent understanding between partners can enhance the attachment towards the relationship (Luo, 2007). As such, exchanges can pave the way for long-term relationships and effective, collaborative partnership work. 


\subsubsection{Perception Of Integrity}

Integrity is "quite possibly the most commonly cited morally desirable trait" (Audi and Murphy, 2006, p. 3 ). There are companies which consider that integrity is likened to quality or wholeness or highest standards of ethics or our commitments (Audi and Murphy, 2006).

According to Tullberg (2012, p. 91) "an agent has integrity if harboring positions of consistency and durability manifested in a correspondence between authentic values, espoused values, and behavior, also persisting in adverse situations".

Perceptions of a partner's integrity enhance feelings of confidence or trust in a relationship. This may be particularly important in complex partnership settings in which work processes as well as concrete outcomes are difficult to foresee. As such, integrity may reduce perceptions of uncertainty (Beckman et al., 2004). Therefore, if consistent patterns of decision-making in a partnership are established and the partner is seen as having integrity, less effort needs to be put in safeguarding from potential opportunistic behavior (Shapiro and Brett, 2005; Williamson, 1975). Instead, more resources can be put into the actual collaboration. Therefore, partner integrity may also act as an important antecedent of partnership effectiveness.

\subsubsection{Partnership Effectiveness}

In partnership work, it is important to recognize what is perceived as effectiveness.

In the main cases the operations literature discusses effectiveness where it is linked to performance, suggesting that for example, effective operations create superior offerings, which in turn is related to economic returns, such as market share and profitability (Panayides, 2007).

However, in partnership work perceptions of what effectiveness may mean could differ according to the circumstances.

An important thing that needs to be considered is the idea that effectiveness between partners can be seen as the achievement of commonly agreed roles. It is through the effectiveness of interrelated and integrated actions that value can be achieved (Panayides, 2007).

\subsubsection{Partnership Value}

Perceived value is seen as an important antecedent of satisfaction (Heskett et al., 2008). The value concept has been widely researched in business to consumer contexts in which often the distinction is made between monetary (i.e. the quality of a product in relation to its price) and non-monetary (i.e. the prestige of a brand or convenience of a service) value terms (Zeithaml, 1988). Less is known about how value can be defined in business to business relationships, such as partner collaboration.

In the strategic alliance literature it is suggested that it is the ultimate financial pay-off that may determine partnership value (Hitt et al., 2000). However, with increased contextual complexity the final financial impact for each partner is difficult to foresee. Moreover, in many partnerships non-monetary aspects may contribute to value perceptions as well, such as advice and support provided. From a monetary perspective, the potential outcome may also be balanced against the costs associated with a transaction. Therefore, the trade-off between input and output can also play an important role. As such, the concept of value for money may contribute to perceptions of partnership value.

\subsubsection{Partner Satisfaction}

The concept has gained great importance in the relationship management as well as services literature over the last two decades (Parasuraman et al., 1985). In essence, satisfaction is an attitude which is formed through experiences over time (Anderson et al. 1994). 
There is evidence that value perceptions have a direct impact on overall satisfaction levels (Heskett et al. 2008). Just like with value, the construct has been widely researched in business to consumer contexts.

In the B2B context, satisfaction is often defined as a positive affective state resulting from the appraisal of all aspects of a firm's working relationship with another firm (Geyskens et al. 1999; Lam et al. 2004). According to Tikkanen et al. (2000, p. 374) "high customer satisfaction often also creates bonding and commitment between interacting parties".

Fewer studies have considered the concept in other types of relationships the firm may have, such as partner satisfaction.

To conclude, we suggest that partner complementarity lays the foundations for mutual exchange between the former as well as perceptions of integrity in a partnership (Buttimer, 2006; Luo, 2002).

We propose that both these concepts are antecedents of partnership effectiveness (Ferrell et al., 2010; Morgan and Hunt, 1994).

Effectiveness in partnership work is an antecedent for the value (Buttimer, 2006; Ferrell et al., 2010). In the end, according to the relationship management literature, value should impact positively on partner satisfaction (Grönroos, 1989; Harker, 1999).

In line with the above we propose the following hypotheses:

H1: The complementarity of partners positively impacts exchange between partners.

H2: The complementarity of partners positively impacts perceptions of partner integrity.

H3: Exchange between partners positively impacts partnership effectiveness.

H4: Perceptions of integrity positively impact partnership effectiveness.

H5: Partnership effectiveness positively impacts perceptions of partnership value.

H6: Partnership value positively impacts partner satisfaction.

Figure 1 shows our conceptual framework. In essence, the model depicts a partner value chain, looking at how value is established in a partner relationship and how this impacts partner satisfaction.

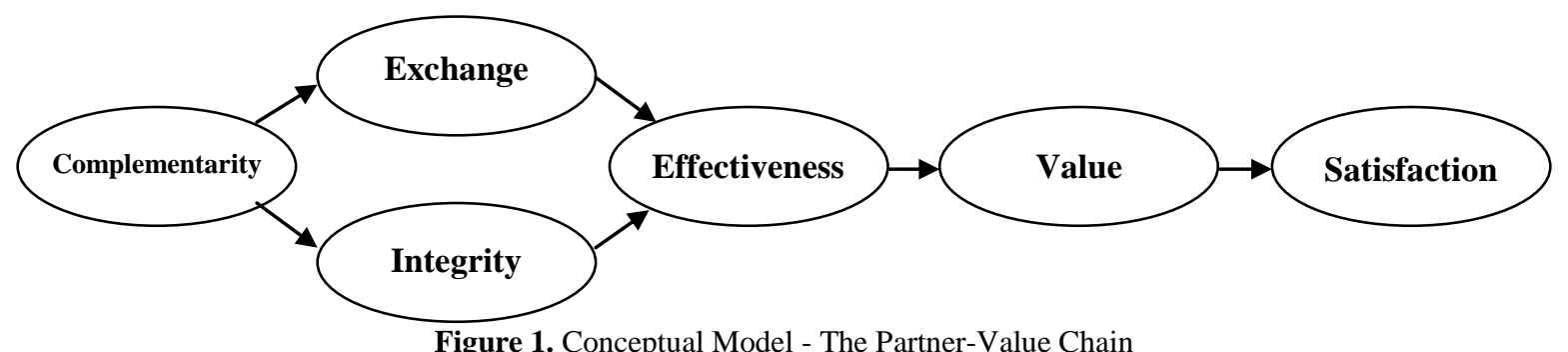

\section{Research Methodology}

As the development of partner orientation is domain and context specific (Pillai and Goldsmith, 2006), it was decided to focus on one single case organization. The organization, a UK-based economic development agency, was chosen on the basis of two specific criteria that made it critical (Yin, 2003) for the investigation of the research objective of this study: 
1) The organization provides complex, knowledge-intense business-to-business services that have to be tailored to customers' needs, such as start-up business advice or consultancy and support for expanding businesses, as well as individual skill development. As such, the organization has to deal with a wide range of different partners, making investigation particularly interesting. Examples of partner organizations mentioned by organizational representatives were trade unions, industry bodies, higher education institutions and local authorities.

2) The development of good relationships with partners is crucial for the organization's performance. Such performance, in this case, is not assessed by measures such as profitability, but the achievement of strategic economic development objectives.

These are critical as they provide the organization with legitimacy in the eyes of resource (e.g. financial or political support) providing entities.

While there is a desire to work with partners in order to contribute positively to the economy and wider society, it also emerged that motivations to do so were highly politicized. Due to the organizational environment of the agency, the boundaries between an instrumental and intrinsic commitment approach to partner orientation (Berman et al., 1999) are blurred.

In order to assess our hypotheses we used a 20-item questionnaire (see Appendix).

All the items are scaled from 1 to 5 . Value 1 expresses strongly disagree while value 5 expresses strongly agree.

The constructs were adapted from the extant literature (Hitt et al., 2000; Luo, 2007; Mittal and Kamakura, 2001; Panayides, 2007; Shah and Swaminathan, 2008; Shapiro and Brett, 2005; Sin et al., 2005).

The questionnaire was sent out to the 264 partner organizations (sampling frame) that were in the organization's database. On-hundred eleven partners replied, equating a response rate of $42 \%$.

The simple size is in line with studies in BtoB context (Ordanini and Rubera, 2008; Camisón and Villar López, 2010; Vanpoucke and Vereecke, 2010).

\section{FINDINGS}

To estimate the model depicted in figure 1 we use the Partial Least Squares (PLS) approach (Wold, 1966; Chin, 1998a, b; Tenenhaus et al. 2005) with XLSTAT software.

We chose PLS approach because it has several advantages over the LISREL (LInear Structural RELationships) approach, particularly important for our study:

- $\quad$ The PLS approach can provide unbiased estimates with small sample size (Vilares et al., 2007),

- $\quad$ PLS is a distribution-free approach (Chin and Newstead, 1999).

The data are analyzed in two sequential stages. First, we tested the measurement model by performing individual item reliability, construct reliability and unidimensionality, convergent and discriminant validity (Bagozzi, 1981; Camisón and Villar López, 2010).

Second, we tested the structural model by estimating the path coefficients between the constructs and the $\mathrm{R}^{2}$ for the endogenous variables.

\subsection{Measurement Model}

The relationships between the measures and their latent variables are assumed to be reflective here (Jarvis et al., 2003). 


\subsubsection{Individual Item Reliability}

To guarantee this criterion, we used factor loadings. The recommended values for this indicator should be above 0.7 (Carmines and Zeller, 1979).

The following table shows that all factor loadings are higher than 0.7, except one item: Sat- favorability. According to Chin (1998b), for the exploratory scales or when it is applied in different contexts, the values between $0.5-0.6$ can be accepted.

Table 1. Factor Loadings

\begin{tabular}{|c|c|}
\hline Latent variable & Loadings \\
\hline \multicolumn{2}{|l|}{ Complementarity } \\
\hline C-actively listens & 0.860 \\
\hline C-recognizes skills & 0.864 \\
\hline C-strong personal contact & 0.878 \\
\hline C-effective relationship & 0.804 \\
\hline \multicolumn{2}{|l|}{ Exchange } \\
\hline Ex-shares info & 0.867 \\
\hline Ex-communicates & 0.857 \\
\hline Ex-offers ideas & 0.831 \\
\hline \multicolumn{2}{|l|}{ Integrity } \\
\hline In-honest & 0.755 \\
\hline In-consistent policy & 0.785 \\
\hline in-sets objectives & 0.853 \\
\hline In-sets outcomes & 0.917 \\
\hline In-sets roles & 0.861 \\
\hline \multicolumn{2}{|l|}{ Effectiveness } \\
\hline Ef-plays active role & 0.747 \\
\hline Ef-positively contributes & 0,871 \\
\hline Ef-delivers its strategy & 0.844 \\
\hline \multicolumn{2}{|l|}{ Value } \\
\hline V-added value & 0.845 \\
\hline V-VFM & 0.853 \\
\hline V-relevant knowledge & 0.760 \\
\hline \multicolumn{2}{|l|}{ Satisfaction } \\
\hline Sat-overall sat & 0.953 \\
\hline Sat- favorability & 0.690 \\
\hline
\end{tabular}

\subsubsection{Construct Reliability And Unidimensionality}

The construct reliability analysis used Dillon-Goldstein's $\rho$ to establish the reliability of each construct. Table 2 shows that all $\rho$ values satisfy the reliability analysis: $\rho>0.7$ (Tenenhaus et al. 2005) and all constructs are uni-dimensional.

Table 2. Reliability And Unidimensionality

\begin{tabular}{lccc}
\hline Latent Variable $(\mathbf{L V})$ & Dillon-Goldstein's $\boldsymbol{\rho}$ & First Eigenvalue & Second Eigenvalue \\
\hline Complementarity & 0.914 & 2.903 & 0.472 \\
Exchange & 0.888 & 2.179 & 0.477 \\
Integrity & 0.920 & 3.497 & 0.633 \\
Effectiveness & 0.863 & 2.032 & 0.579 \\
Value & 0.861 & 2.022 & 0.627 \\
Satisfaction & 0.837 & 1.439 & 0.561 \\
\hline
\end{tabular}

Convergent validity is checked using Average Variance Extracted (AVE) (Fornell and Larcker, 1981; Chin, 1998b). According to Chin (1998b), constructs with AVE $\geq 0.50$ are said to exhibit convergent validity (see also Fornell and Larcker, 1981). Table 3 indicates that all AVE exceed 0.50, confirming that all constructs demonstrate satisfactory convergent validity. 
Table 3. Average Variances Extracted

\begin{tabular}{|l|c|}
\hline Latent Variable & Average Variances Extracted (AVE) \\
\hline Complementarity & 0.726 \\
\hline Exchange & 0.726 \\
\hline Integrity & 0.699 \\
\hline Effectiveness & 0.677 \\
\hline Value & 0.673 \\
\hline Satisfaction & 0.692 \\
\hline
\end{tabular}

Discriminant validity is determined from the latent variable correlation matrix. The following table presents the correlations between the latent variables in the lower left, off-diagonal elements of the matrix, and the square root of the AVE. Discriminant validity is satisfactory if the diagonal values are larger than off-diagonal values (Fornell and Larker, 1981). Table 4 shows that this condition has been satisfied.

Table 4. The Latent Variable Correlation Matrix With Square Root Of AVE On The Diagonal

\begin{tabular}{lcccccc}
\hline & Complementarity & Exchange & Integrity & Effectiveness & Value & Satisfaction \\
\hline Complementarity & $\mathbf{0 . 8 5 2}$ & 0.781 & 0.765 & 0.550 & 0.690 & 0.680 \\
Exchange & & $\mathbf{0 . 8 5 2}$ & 0.735 & 0.535 & 0.591 & 0.499 \\
Integrity & & $\mathbf{0 . 8 3 6}$ & 0.699 & 0.716 & 0.593 \\
Effectiveness & & & $\mathbf{0 . 8 2 3}$ & 0.702 & 0.547 \\
Value & & & & $\mathbf{0 . 8 2 0}$ & 0.623 \\
Satisfaction & & & & & $\mathbf{0 . 8 3 2}$ \\
\hline
\end{tabular}

\subsection{Structural Model}

The main PLS results for this analysis are the follows:

Path coefficients and their statistical significance. Because PLS is a distribution-free approach, we used the bootstrapping resampling technique to determine the significance of the path coefficients. As recommended by Chin (1998b), 500 samples were used in performing the bootstrap.

The results reported in the Table 5 reveal that all our hypotheses are supported (p-value $=0$ ) at the 5\% level, except $\mathrm{H} 3$ (exchange between partners positively impact partnership effectiveness).

$R^{2}$ values. As we can see in Table 5 all $\mathrm{R}^{2}>0.38$, suggesting a very satisfactory predictive power (Falk and Miller, 1992).

The results indicate that the overall model fit, estimated using the Goodness of Fit $(\mathrm{GoF})$ index is satisfactory: $\mathrm{GoF}=0.600$, which is superior to the recommended level of 0.5 (Tenenhaus et al. 2005).

Table 5. Results Of Structural Model

\begin{tabular}{lcccccc}
\hline $\begin{array}{l}\text { Dependent } \\
\text { Variable }\end{array}$ & $\mathbf{R}^{\mathbf{2}(\boldsymbol{\%})}$ & $\begin{array}{c}\text { Explanatory } \\
\text { Variable }\end{array}$ & $\begin{array}{c}\text { Contribution } \\
\text { to } \mathbf{R}^{\mathbf{2}} \mathbf{( \% )}\end{array}$ & Path coefficient & Student's t & p-val \\
\hline Exchange & 0.611 & Complementarity & 100 & 0.781 & 13.077 & 0.000 \\
Integrity & 0.586 & Complementarity & 100 & 0.765 & 12.419 & 0.000 \\
Effectiveness & 0.490 & Exchange & 4.904 & 0.045 & 0.443 & 0.659 \\
Value & 0.493 & Integrity & 95.096 & 0.666 & 6.570 & 0.000 \\
Satisfaction & 0.388 & Effectiveness & 100 & 0.702 & 10.291 & 0.000 \\
\hline
\end{tabular}

\section{DISCUSSION}

Not-for-profit organizations have become major elements within the economies of countries throughout the world (Olson et al. 2005). According to Andrews and Entwistle (2010, p. 679) "public services are increasingly 
characterized by hybrid forms of organization variously described as partnerships, collaborations, networks, or alliances" (see also Gulati et al. 2000).

The purpose of this research is to investigate in a complex public sector context what components form a part of partner orientation and how they lead to partner satisfaction.

The results of this study are as follows. integrity.

Complementarity of partners has a major effect on both exchange between partners and perception of

As suggested by Andrews and Entwistle (2010, p. 680 ) "the turn to partnership in the public sector is often explained by the drive to maximize the return from scarce resources". In this context complementarity of partners is important because when partners have complementary skills and resources, exchange between them and their integrity are facilitated.

Therefore, to improve exchange between partners and their integrity, managers should pay greater attention to complementarity of partners.

It was hypothesized that the exchange between partners and perception of integrity would have a positive impact on the partnership effectiveness ( $\mathrm{H} 3$ and $\mathrm{H} 4)$.

Unexpectedly, our results indicate that the $\mathrm{H} 3$ is not supported (path coefficient $=0.045$ and $\mathrm{p}$ value $=0.659$ ).

This is surprising, because, "partners should work together in a collaborative manner, with a willingness to share and receive information and improve efficiency and effectiveness" Panayides (2007).

The findings indicate that integrity is particularly important for partner effectiveness (contribution to $\mathrm{R}^{2}$ of partnership effectiveness: 95\%).

From a managerial point of view, it is essential to understand the determinants of effectiveness, "because organizational perceptions will determine their willingness to enter and invest in such relationships" (Chen and Graddy, 2010).

Thus, to improve partnership effectiveness, managers must reinforce a culture of integrity by clarifying and combining it with other valuable elements, such as transparency in communication and action.

Partnership effectiveness is considered as an essential means to generate value for partners. Our results show that partnership effectiveness has a positive impact on partnership value (path coefficient $=0.702, \mathrm{p}$-value $=$ 0.000). From a managerial perspective this is important because an effective partnership is efficient in both economic and technical aspects and creates value for stakeholders.

Our study stresses the importance of partnership value in the formation of partner satisfaction (path coefficient $=0.623$, p-value $=0.000$ ). As highlighted by Lepak et al. (2007), "it essential to understand not only how value is created, but also the consequences of value creation".

Further, partnership value explains $\approx 39 \%$ of the variance of the partner satisfaction. Therefore, this result suggests that by creating superior partnership value firms can improve partner satisfaction and then competitive advantage.

From a relationship orientation perspective (Grönroos, 1989; Harker, 1999) the achievement of partner satisfaction can be seen as being particularly important, as it forms the basis for partners' willingness to remain in a partnership. This is crucial in public sector contexts in which partnership work is usually concerned with the 
achievement of long-term strategic objectives. Moreover, it is also likely that partner satisfaction enhances the legitimacy of the organization, as it enhances the organization's profile and acceptance amongst a wider audience. Therefore, in line with institutional theory, the organization should be in a better position to extract resources from its environment more easily (Deephouse, 1996), particularly important in the face of public austerity measures in times of economic crises.

\section{CONCLUSIONS}

As outlined above, an orientation towards different stakeholder groups has gained considerable interest in the marketing management literature over the last three decades, as there is some evidence that it may contribute to long-term organizational success (Ferrell et al., 2010). Stakeholder orientation can thus be seen as a contributor to the achievement of strategic organizational objectives. While the majority of studies have focused on the orientation towards stakeholder groups such as customers, competitors, employees and shareholders (e.g., Kohli and Jaworski, 1990), in the literature organizational partners have been widely neglected.

However, the strategic alliance literature clearly highlights the importance of effective selection and collaboration with partners in order to attain a positive impact on organizational performance in the long run (Luo, 2002). For this reason our study focused on what components form a part of partner orientation in a complex public sector context and how they lead to partner satisfaction. As public sector institutions are increasingly dependent on partnership work with other public as well as private organizations (Buttimer, 2006; Hayes, 2002), our study is of particular interest to public administration.

Our findings reveal five main components that define partner orientation:

- Complementarity - meaning mutual goal alignment through recognition of others, active listening, strong personal contact and effective in relationship work;

- $\quad$ Exchange between partners - which relates to effective communication, ideas to partners, information sharing;

- Integrity - in terms of honesty, consistency, objectives and respect;

- Partnership Effectiveness - in terms of active policy development, positive contribution to partner objectives and strategies;

- $\quad$ Partnership Value - in relation to employees' relevant knowledge, added value services, as well as value for money.

These results provide an important insight into how partner orientation can be developed and form the basis for managerial guidelines on how to manage partner work.

We have further contributed to the extant literature by demonstrating that partnership value has a strong impact on partner satisfaction. Therefore, we have provided empirical evidence for the antecedents of partner satisfaction.

Our results have also shown that partnership effectiveness is the main driver for perceived value. Therefore, managers should pay great attention to the role of partnership effectiveness in the public sector context and more specifically the following: active policy development, positive contribution to partner objectives, and strategies.

To conclude we have provided some limitations that offer opportunities for future research.

Our study was conducted in a UK context. Future research might test the proposed model with data collected from another country and use the results of our research as a comparative benchmark.

Second, our research did not test the model across different points in time, but explore how partner satisfaction can be enhanced over time is crucial in public sector contexts. Therefore, we suggest carrying out a longitudinal survey. 
Finally, we have not integrated trust in our framework. Future research might try to examine the relationship of trust with partner satisfaction and perceived value.

\section{AUTHOR INFORMATION}

\section{Valentina Stan}

Ph.D., Associate Professor of Marketing, ESSCA School of Management, 55 Quai Alphonse Le Gallo, 92513 Boulogne Billancourt Cedex, France. Dr. Stan received her Ph.D from CNAM Paris. Her research interests include customer satisfaction and loyalty, Structural Equation Modelling. E-mail: valentina.stan@essca.fr (Corresponding author)

\section{Barbara Caemmerer}

Professor of Marketing, ESSCA School of Management, 55 Quai Alphonse Le Gallo, 92513 Boulogne Billancourt Cedex, France. Before joining ESSCA as a Professor, Barbara worked for several years in the Department of Marketing at the University of Strathclyde, Glasgow, where she also earned her PhD. Barbara's research interest is in the field of services marketing and management, as well as franchising.

\section{REFERENCES}

1. Anderson, E.W., Fornell, C., \& Lehmann, D.R. (1994). Customer satisfaction, market share, and profitability: Findings from Sweden. Journal of Marketing, 58, 53-66.

2. Andrews, R., \& Entwistle, T. (2010). Does cross-sectoral partnership deliver? an empirical exploration of public service effectiveness, efficiency, and equity. Journal of Public Administration Research and Theory, 20, 679-701.

3. Audi, R., \& Murphy P.E. (2006). The many faces of integrity. Business Ethics Quarterly, 16(1), 3-21.

4. Bagozzi, R.P. (1981). An examination of the validity of two models of attitude. Multivariate Behavioral Research, 16(July), 323-359.

5. Beckman, C., Haunschild, P., \& Philips, D. (2004). Friends or strangers? Firm-specific uncertainty, market uncertainty, and network partner selection. Organization Science, 15(3), 259-275.

6. Berman, S.L., Wicks, A.C., Kotha, S., \& Jones, T.M. (1999). Does stakeholder orientation matter? The relationship between stakeholder management models and firm financial performance. Academy of Management Journal, 42(5), 488-506.

7. Buttimer, L. (2006). Achieving public sector outcomes with private sector partners - a New Zealand perspective. International Journal of Government Auditing, 33(4), 23-26.

8. Camisón, C. \& Villar López, A. (2010). An examination of the relationship between manufacturing flexibility and firm performance - the mediating role of innovation. International Journal of Operations \& Production Management, 30(8), 853-878.

9. Carmines, E.G. \& Zeller, R.A. (1979). Reliability and validity assessment, Newbury Park, CA: Sage.

10. Chen, B., \& Graddy, E.A. (2010). The effectiveness of nonprofit lead-organization networks for social service delivery. Nonprofit Management \& Leadership, 20(4), 405-422.

11. Chin, W.W. (1998a). Issues and opinion on structural equation modeling. MIS Quarterly, 22(1), 7-16.

12. Chin, W.W. (1998b). The partial least squares approach to structural equation modelling. In Marcoulides, G.A. (Ed.), Modern Methods for Business Research (295-336). Mahwah, NJ: Lawrence Erlbaum Associates.

13. Chin, W.W., \& Newsted, P. R. (1999). Structural Equation Modeling Analysis with Small Samples Using Partial Least Squares. In R. H. Hoyle (Ed.), Statistical Strategies for Small Sample Research (307-341). Thousand Oaks, CA: Sage Publications.

14. Chung, S., Singh, H., \& Lee, K. (2000). Complementarity, status similarity and social capital as drivers of alliance formation. Strategic Management Journal, 21, 1-22.

15. Deephouse, D. (1996). Does isomorphism legitimate?. Academy of Management Journal, 39, 1024-1040.

16. DiMaggio, P., \& Powell, W. (1983). The iron cage revisited: institutional isomorphism and collective rationality in organizational fields. American Sociological Review, 48, 147-160.

17. Eweje, G., \& Palakshappa, N. (2011). Stakeholder collaboration in New Zealand, adding value and legitimacy. Journal of Corporate Citizenship, 43, 79-101. 
18. Falk, R.F., \& Miller, N.B. (1992), A primer for SoftModelling. Akron, OH: The University of Akron.

19. Ferrell, O.C., \& Ferrell, L. (2008). A macromarketing ethics framework: stakeholder orientation and distributive justice. Journal of Macromarketing, 28(1), 24-32.

20. Ferrell, O.C., Gonzalez-Padron, T.L., Hult, G.T., \& Maignan, I. (2010). From market orientation to stakeholder orientation. Journal of Public Policy and Marketing, 29(1), 93-96.

21. Fornell, C. \& Larcker, D. (1981), Evaluating structural equation models with unobservable variables and measurement error. Journal of Marketing Research, 18, 39-50.

22. Freeman, E.R. (1984). Strategic management: a stakeholder approach. Boston: Pittman.

23. Geyskens, I., Steenkamp, J-B. E.M., \& Kumar. N. (1999). A meta-analysis of satisfaction in marketing channel relationships. Journal of Marketing Research, 36, 223-238.

24. Grönroos, C. (1989). Defining marketing: a market-oriented approach. European Journal of Marketing, 23(1), 52-60.

25. Gulati, R., Nitin, N., \& Zaheer, A. (2000). Strategic networks. Strategic Management Journal, 21, 2032015.

26. Harker, M.J. (1999). Relationship marketing defined? An examination of current relationship marketing definitions. Marketing Intelligence and Planning, 17(1), 13-20.

27. Harrison, J., Hitt, M., Hoskisson, R., \& Ireland, R. (2001). Resource complementarity in business combinations: extending the logic to organizational alliances. Journal of Management, 27(6), 679-690.

28. Hayes, T. (2002). The non-profit sector, government and business: partners in the dance of change - an Irish perspective. Public Management Review, 4(2), 257-264.

29. Heskett, J.L., Jones, T.O., Loveman, G.W., Sasser, W.E. \& Schelsinger, L.A. (2008). Putting the serviceprofit chain to work. Harvard Business Review, 86(7/8), 118-129.

30. Hitt, M., Dacin, T., Levitas, E., Arregle, J., \& Borza, A. (2000). Partner selection in emerging and developed market contexts: resource-based and organizational learning perspectives. Academy of Management Journal, 43(3), 449-467.

31. Jarvis, C.B., MacKenzie, S.B., \& Podsakoff, P.M. (2003). A critical review of construct indicators and measurement model misspecification in marketing and consumer research. Journal of Consumer Research, 30 (2), 199-218.

32. Kohli, A.K., \& Jaworski, B.J. (1990). Market orientation: the construct, research propositions, and managerial implications, Journal of Marketing, 54 (April), 1-18.

33. Lam, S.Y., Shankar, V., Erramilli M.K., \& Murthy, B. (2004). Customer value, satisfaction, loyalty, and switching costs: an illustration from a business-to-business service context. Journal of the Academy of Marketing Science, 32(3), 293-311.

34. Lepak, P.D., Smith, K.G., \& Taylor, S.M. (2007). Introduction to special topic forum: value creation and value capture: a multilevel perspective, Academy of Management Review, 32, 180-194.

35. Luo, Y. (2002). Contract, cooperation, and performance in international joint ventures. Strategic Management Journal, 23(10), 903-919.

36. Luo, Y. (2007). Procedural fairness and interfirm cooperation in strategic alliances. Strategic Management Journal, 29, 27-46.

37. Maddock, S. (2002). Making modernisation work - new narratives, change strategies and people management in the public sector. International Journal of Public Sector Management, 15(1), 13-43.

38. Micheli, P., Mason, S., Kennerley, M., \& Wilcox, M. (2005). Public sector performance: efficiency or quality?. Measuring Business Excellence, 9(2), 68-74.

39. Mittal, V. \& Kamakura, W.A. (2001). Satisfaction, repurchase intent, and repurchase behavior: investigating the moderating effect of customer characteristics. Journal of Marketing Research, 38(1),131142 .

40. Mizruchi, M., \& Fein, L. (1999). The social construction of organizational knowledge: A study of the uses of coercive, mimetic and normative isomorphism. Administrative Science Quarterly, 44, 653-683.

41. Nonaka, I. (1994). A dynamic theory of organizational knowledge creation. Organization Science, 5, 1437.

42. Morgan, R.M, \& Hunt, S.D. (1994). The commitment-trust theory of relationship marketing. Journal of Marketing, 58, 20-38. 
43. Olson, J.R., Belohlav, J., \& Boyer, K. (2005). Operational, economic and mission elements in not-for-profit organizations: the case of the Chicago Symphony Orchestra, Journal of Operations Management, 23, 125 142.

44. Ordanini, A., \& Rubera, G. (2008). Strategic capabilities and internet resources in procurement a resourcebased view of B-to-B buying process, International Journal of Operations \& Production Management, 28(1), 27-52

45. Panayides, P. (2007). The impact of organisational learning on relationship orientation, logistics service effectiveness and performance. Industrial Marketing Management, 36, 68-80.

46. Parasuraman, A., Zeithaml, W. \& Berry, L. (1985). A conceptual model of service quality and its implications for future research. Journal of Marketing, 49(4), 41-50.

47. Pillai, K.G., \& Goldsmith, R.E. (2006). Calibrating managerial knowledge of customer feedback measures: a conceptual model. Marketing Theory, 6(2), 223-243.

48. Shah, R., \& Swaminathan, V. (2008). Factors influencing partner selection in strategic alliances: the moderating role of alliance context. Strategic Management Journal, 29, 471-494.

49. Shapiro, D.L., \& Brett, J.M. (2005). What is the role of control in organizational justice? In Greenberg. J., \& Colguitt, J.A. (Eds.), Handbook of Organizational Justice (155-178), Mahwah, NJ: Erlbaum.

50. Sin, L.Y., Tse, A.C., Yau, O.H., Chow, R.P., Lee, J.S., \& Lau, L.B. (2005). Relationship marketing orientation: scale development and cross-cultural validation. Journal of Business Research, 58, 185-194.

51. Tikkanen, H., Alajoutsijärvi, K., Tähtinen, J. (2000). The concept of satisfaction in industrial markets: a contextual perspective and a case study from the software industry. Industrial Marketing Management, 29, 373-386.

52. Tenenhaus, M., Vinzi, V.E., Chatelin, Y.-M., \& Lauro, C. (2005). PLS path modeling. Computational Statistics \& Data Analysis, 48(1), 159-205.

53. Tullberg, J. (2012). Integrity - clarifying and upgrading an important concept for business ethics. Business and Society Review, 117(1), 89-121.

54. Vanpoucke, E., \& Vereecke A. (2010). The predictive value of behavioural characteristics on the success of strategic alliances. International Journal of Production Research, 48(22), 6715-6738.

55. Vilares, M., Almeida, M., Coelho, P. (2007). Sample size effect on the comparison of likelihood and PLS estimation for structural equation modeling: a simulation with customer satisfaction data. In: PLS'07 International Symposium, Aas, Norway. 39, 41.

56. Williamson, O. (1975). Markets and Hierarchies. New York: Free Press.

57. Wold, H. (1966). Estimation of principal components and related models by iterative least squares. In

58. P.R. Krishnaiah (Ed.), Multivariate Analysis (391-420). New York: Academic Press.

59. Yin, R. K. (2003). Case study research: Design and methods (3rd ed.). Thousand Oaks, CA: Sage.

60. Zeithaml, V. (1988). Consumer perceptions of price, quality, and value: a means-end model and synthesis of evidence. Journal of Marketing, 52(3), 2-22. 


\section{APPENDIX}

\section{Questionnaire items}

\section{Complementarity of partners}

Actively listens to what others are suggesting (C-actively listens)

Recognizes skills that others bring (C-recognizes skills)

Builds strong personal contact (C-strong personal contact)

Employees are effective in relationship work (C-effective relationship)

\section{Exchange between partners}

Shares information (Ex-shares info)

Communicates effectively (Ex-communicates)

Offers ideas to partners (Ex-offers ideas)

\section{Perception of integrity}

Honest about what they can achieve (In-honest)

Consistent in terms of policy and inclusiveness (In-consistent policy)

Sets and agrees shared objectives (In-sets objectives)

Sets and agrees expected outcomes (In-sets outcomes)

Sets and agrees on respective roles (In-sets roles)

\section{Partnership Effectiveness}

Plays an active role in delivering policy (Ef-plays active role)

Positively contributes to the economy (Ef-positively contributes)

Delivers against its strategy (Ef- delivers its strategy)

\section{Partnership Value}

Employees have relevant knowledge (V-relevant knowledge)

Provides relevant added value to partners ( $\mathrm{V}$-added value)

Provide value for money (V-VFM)

\section{Partner Satisfaction}

Overall satisfaction with the relationship you have with the organization How favorable is your overall opinion of the organization's network 